\title{
How the Euro-Area Sovereign-Debt Crisis Led to a Collapse in Bank Equity Prices*
}

\author{
Heather D. Gibson \\ Bank of Greece \\ Stephen G. Hall \\ University of Leicester \\ Bank of Greece \\ George S. Tavlas** \\ Bank of Greece \\ University of Leicester
}

June 2015

\begin{abstract}
We quantify the linkages among banks' equity performance and indicators of sovereign stress by using panel GMM to estimate a three-equation system that examines the impact of sovereign stress, as reflected in both sovereign spreads and sovereign ratings, on bank share prices. We use data for a panel of five euro-area stressed countries. Our findings indicate that a long-run recursive relationship between sovereigns and banks operated during the euro-area crisis. Specifically, for the five crisis countries considered shocks to sovereign spreads fed-through to sovereign ratings, which affected commercial banks' equity-prices. Our results also point to the importance of using levels of equity prices -- rather than rates of return - in measuring banks' performance. The use of levels allows us to derive the determinants of long-run equity prices.
\end{abstract}

Keywords: euro-area financial crisis, sovereign-bank linkages, banks' performance, banking stability

JEL Classification: E3, G01, G14, G21

* We are grateful to three referees for their very helpful comments on an earlier version of the paper.

**Corresponding author: George Tavlas, Bank of Greece, 21 E Venizelos Ave, Athens, 10250, Greece, Tel. no. +30 210320 2370; Fax. no. +30 210320 2432; Email address: gtavlas@bankofgreece.gr 
How the Euro-Area Sovereign-Debt Crisis Led to a Collapse in Bank Equity Prices

\section{Introduction}

In this paper, we investigate the impact of the euro-area sovereign debt crisis on the price of bank equity for a group of five euro-area stressed countries -- Greece, Ireland, Italy, Portugal and Spain. Using monthly data, we cover the period from October 1998 through July 2014. Although previous empirical studies have investigated the determinants of banks' equity performance, the focus of those studies has largely been on the bank-specific determinants of excess returns on bank stocks. Some studies have included variables reflecting macroeconomic conditions that could affect banks' expected future returns or the systematic component of bank equity returns, but only several papers (to which we refer in the next section) have dealt with the impact of the crisis. However, none of these studies (to our knowledge) has dealt in a comprehensive way with the linkages between banks' equity performance and sovereign stress indicators.

A major characteristic of the euro-area financial crisis, especially in the stressed countries has been the strong linkages between banks' performance and sovereign stress (Pisani-Ferry, 2014, pp. 101-02) as downward revisions of markets' assessments of sovereigns impacted negatively on banks' financial conditions. Deteriorations in sovereign creditworthiness during the crisis affected banks' equity performance through several channels (BIS, 2011): (i) the direct effects of banks' holdings of sovereign debt on banks' balance sheets and profitability; (ii) the reduction in the value of collateral available to banks to obtain wholesale funding and/or central-bank financing; and (iii) the reduced benefits from the implicit guarantee that, should the need arise, the state would step in to help honour banks' financial commitments.

The above linkages played-out in a number of advanced economies -- both within and outside the euro area -- during the global financial crisis that erupted in 2007-08. However, European banks are particularly vulnerable to sovereign risk due to a number of factors. First, national banking systems tend to be especially large in the euro area. In 2012, for example, total bank assets as a share of euro-area GDP was almost 360 per cent, compared with less than 80 per cent in the United States (Shambaugh, 2012). 
Second, firms in the euro area are much more reliant on the banking system for finance than are U.S. firms; banks account for about three-quarters of total credit intermediation in the euro area, compared with about one-quarter in the United States. Third, domestic euro-area banks typically hold relatively-large shares of debt issued by their respective national governments in their portfolios, leaving banks' balance sheets vulnerable to doubts about sovereign solvency. In contrast, U.S. banks typically hold small amounts of local and state debt on their balance sheets; U.S. banks mainly hold U.S. government debt as their safe liquid assets ( $O^{\prime}$ Rourke and Taylor, 2013, p. 181). Consequently, defaults by U.S. state and local governments have not involved financialstability concerns for the U.S. financial system, in marked contrast to the concerns about euro-area financial stability raised by the restructuring of Greek sovereign debt in 2012.

The contribution of this paper is to quantify the linkages among banks' equity performance and indicators of sovereign stress by using panel GMM to estimate a threeequation dynamic fixed-effects system that examines the impact of sovereign stress, as reflected in both sovereign spreads and sovereign ratings, on bank share prices. Moreover, for reasons that we explain below -- and unlike previous studies -- we do not focus on bank performance as measured by equity returns (i.e., the change in equity prices). Instead, we focus on (the log of) the level of equity prices.

The remainder of the paper consists of four sections. Section 2 provides a brief literature review. Section 3 describes our data and empirical model. Section 4 presents the results; the results indicate that the distress of the sovereign has had an important impact on bank equity prices. Section 5 concludes.

\section{Literature Review}

\subsection{Bank performance}

Prior to the outbreak of the 2007-08 global financial crisis, the empirical literature on bank performance mainly focused on the determinants of bank profitability and bank stock returns. Among the factors that were found to influence bank performance were the following: (1) measures of market characteristics, including economies of scale, management efficiency, and bank size; (2) bank characteristics, including capital 
positions, loan-to-deposit ratios, and equity-to-total assets ratios; and (3) indicators of macroeconomic performance, including economic growth and the state of the business cycle. Recent studies that take into account the crisis period (beginning in 2007) include Yang and Tsatsaronis (2012), Chan-Lau, Liu and Schmittmann (2014) and Castrén, Fitzpatrick and Sydow (2006). ${ }^{1}$

The effects of sovereign risk on bank performance have been less researched than the factors (i.e., bank characteristics and indicators of macroeconomic performance) mentioned above. The BIS (2011) found that the rise in sovereign risk after 2009 pushed up the cost, and adversely affected the composition, of some euro area banks' funding, with the extent of the impact broadly related to the deterioration in the credit worthiness of the home sovereign. Demirgüç-Kunt, Detragiache and Merrouche (2013) found that increases in bank CDS premia during the crisis were significantly related to deterioration in bank capital positions as well as public finances. Chan-Lau, Liu and Schmittmann (2014) examined the impact of sovereign risk, measured as the arithmetic average of the five-year CDS spreads of Belgium, Greece, Ireland, Italy, Portugal, and Spain, on equity returns of euro-area (and other banks); the authors found that, for the period 2008-10, equity returns in excess of a risk-free rate of return were driven mainly by the economic-growth outlook (as measured by the Purchasing Managers' Indices of both the euro area and the United States) and sovereign risk.

\subsection{Indicators of sovereign stress}

The recent macro-international finance literature has focused on two measures of sovereign stress or risk -- (1) spreads on government bond yields, and (2) CDS spreads. As Aizenman, Hutchison and Lothian (2013, p. 41) pointed out, however, recent studies suggest that both reference measures have common underlying determinants, rather than being entirely separate measures. ${ }^{2}$

Studies focusing on euro-area countries have found that macroeconomic fundamentals played an important role in determining sovereign bond spreads or CDS

\footnotetext{
${ }^{1}$ Chan-Lau, Liu and Schmittmann (2014) provide a thorough review of the earlier literature on the determinants of banks' performance.

${ }^{2}$ See, also, Ammer and Cai (2007) and Fontana and Scheicher (2010).
} 
spreads (e.g., Dötz and Fischer, 2010; Gibson, Hall, and Tavlas, 2012; Aizenman, Hutchison, and Jinjarak, 2013; Beirne and Fratzscher, 2013; De Grauwe and Ji, 2013). ${ }^{3}$ Typical determinants have been found to include indicators reflecting fiscal imbalances, current-account imbalances and growth. ${ }^{4}$ Gerlach, Schulz and Wolff (2010) assessed the impact of the size and structure of a country's banking sector on euro-area sovereign spreads, and found that the size of the banking sector is a positive determinant of a country's spread; as of early 2009, almost one percentage point of euro-area sovereign spreads could be explained by this factor. In a study of the determinants of Greek sovereign spreads, Gibson, Hall, and Tavlas (2014) found that sovereign ratings' downgrades and political uncertainty were the main drivers of spreads from 2008-09 onwards, over-and-above the impact of the economic fundamentals.

\section{Data and empirical model}

To examine the links between sovereign stress indicators and banks' equity performance, we estimate a three-equation panel system in which bank equity prices, sovereign bond spreads and sovereign ratings are endogenous variables. This system framework allows us to fully explore the impact that sovereign stress can have on bank equity prices. As the sovereign becomes more stressed, sovereign spreads rise and ratings fall. This circumstance would be expected to impact on banks' market values. Market values fall as confidence in the ability of the state to meet potential obligations to banks - either direct obligations resulting from banks' holdings of sovereign assets, or indirect obligations through state guarantees - comes into question. Thus, in addition to bank-specific variables, we include sovereign spreads and sovereign ratings as determinants of banks' equity performance.

We focus on the level of bank equity prices, and not equity returns. The reason is as follows. As mentioned above, if sovereign spreads rise and sovereign ratings fall, then we expect bank equity prices to fall. Initially, this fall in the level of equity prices will be associated with negative equity returns. If spreads and ratings stabilize at new levels

\footnotetext{
${ }^{3}$ Typically, the literature has found roles for other factors, including measures of international market volatility and capital flows into government bond markets, as drivers of sovereign risk.

${ }^{4}$ Gibson, Hall, and Tavlas (2012) provide a more-thorough review of the literature.
} 
(higher levels for spreads and lower levels for ratings), equity returns will go back to zero -- that is, returns will improve from a negative number to a number that approaches (or equals) zero, even though spreads may remain high and ratings may remain low. This situation would give the (paradoxical) result that equity returns improve while sovereign stress indicators remain at extreme levels. Consequently, the appropriate relationship involves sovereign spreads, sovereign ratings and the level of equity prices (and not the rate of change of equity prices). A similar argument can be made with respect to the bank-specific variables. For example, if the capital ratio falls and then stabilises at a lower level, we would expect the value of banks' equities to fall, and then to stabilize at a lower level. Returns would be highly negative, but would then go back to more-normal levels, even though the capital ratio remained low.

This circumstance suggests that, in focusing on equity returns, previous studies have been mis-specifying the relationship since they have overlooked the effect on the level of equity prices. The figures presented in Appendix I drive home this point. They show the level of the equity index and equity returns for each of the countries examined here for the period October 1998 until July 2014. It is clear from these figures that equity returns move around zero throughout the period and that the crisis period (beginning in 2007) is associated with a rise in volatility rather than a particular trend. By contrast, as also shown in Appendix I, the level of the equity price index appears to be a more appropriate measure of bank health; that index exhibited a steady decline as sovereign spreads and sovereign ratings increased. (As we discuss below, our measure of sovereign ratings is constructed in such a way that a rise in our measure is associated with a downgrade of the sovereign.)

As noted, we focus on five stressed euro area countries - Spain, Greece, Ireland, Italy and Portugal. Figures 1-5 plot the three dependent variables for each country. The bank equity index is the FTSE index for the banking sector for each country ${ }^{5}$. Sovereign bond spreads are the yield on the 10-year benchmark bond in each country relative to that of Germany. Sovereign ratings are those assigned to the sovereigns by the three

\footnotetext{
${ }^{5}$ For data sources, see Appendix II. Note, also, that the data are scaled to facilitate their presentation in a single figure. Thus, spreads are presented in basis points and sovereign ratings, which range between 1 and 22 in the original data, are multiplied by 10 for display in the figures.
} 
main ratings agencies, Moody's, Standard and Poor's (S\&P) and Fitch. We convert the ordinal series to a cardinal series by assigning values of 1-22 to different possible ratings - the higher the value, the lower the rating. In light of the fact that rating changes by the three agencies often occurred in waves, the rating assigned in each period depends on which of the three agencies moved first to change a particular rating. In this way, we capture what might be termed "important" rating downgrades or upgrades. ${ }^{6}$

Looking across Figures 1 to 5, a number of stylized facts can be identified. First, bank equity prices, which had been rising relatively steeply in all five countries before the failure of Lehman Brothers (in September 2008), fell sharply thereafter. This decline was then following by a small recovery - the size of which is closely related to banks' involvement in the type of assets which sparked Lehman's failure - before the outbreak of the euro area sovereign debt crisis (in late 2009 and early 2010) sent bank equity prices falling again (in some countries, e.g., Greece and Ireland, bank equity prices remained at low levels through the end of our sample period). Second, spreads rose slightly in light of the turmoil associated with the failure of Lehman Brothers; it was not, however, until the sovereign crisis (beginning in late 2009 and 2010) that they underwent sharp rises. Third, sovereign ratings started deteriorating in 2009 in Ireland (associated with concerns about the fiscal cost of the banking crisis), Greece, and Portugal (concerns about the level of public debt in the former country and the total of public and private debt in the latter country) and, then, in 2011 in Spain (reflecting the fiscal consequences of the banking crisis following the collapse of the housing boom), and Italy (related to concerns about size of public debt). The final stylized fact is the close interconnection between movements in equity prices, spreads and ratings. Indeed, there appears to be a strong negative correlation between equity prices and sovereign spreads and, to a lesser extent, between sovereign ratings and banks' equity prices.

These stylized facts motivate our three-equation system, which is estimated as a panel GMM system which is robust to autocorrelation and heteroskedasticity (HAC). We

\footnotetext{
${ }^{6}$ Although the three ratings agencies use different names for their ratings, all three have 22 categories which are compatible in terms of their interpretation. We have constructed an index to represent all three agencies, where movements in our index coincide with the first agency to move.
} 
are interested in a three-equation dynamic simultaneous system for a group of $\mathrm{N}$ countries, estimated over T periods. Our baseline model can be expressed as:

$$
\begin{aligned}
& S_{i t}=\alpha_{0 i}+\alpha_{1} S R_{i t}+\alpha_{2} B E_{i t}+\alpha_{3} S_{i t-1}+\sum_{k=1}^{K} \alpha_{3+k} X_{i t k}+\varepsilon_{i t} \\
& S R_{i t}=\beta_{0 i}+\beta_{1} S_{i t}+\beta_{2} B E_{i t}+\beta_{3} S R_{i t-1}+\sum_{k=1}^{K} \beta_{3+k} X_{i t k}+\varpi_{i t} \\
& B E_{i t}=\chi_{0 i}+\chi_{1} S_{i t}+\chi_{2} S R_{i t}+\chi_{3} B E_{i t-1}+\sum_{k=1}^{K} \chi_{3+k} X_{i t k}+v_{i t}
\end{aligned}
$$

where $\mathrm{i}=1 \ldots \mathrm{N}, \mathrm{t}=1 \ldots \mathrm{T}$ and $\mathrm{K}$ is the number of exogenous regressors. $S_{i t}$ is the interest rate spread between country $\mathrm{i}$ and Germany, $S R_{i t}$ is the sovereign rating for country $\mathrm{i}, \mathrm{BE} \mathrm{E}_{\mathrm{it}}$ is the (log of the) equity price for commercial banks in country $\mathrm{i}$ and $\varepsilon_{i t}, \omega_{i t}$ and $v$ are error terms and $\alpha_{0 i} \beta_{0 i}$ and $\chi_{0 i}$ are fixed effects in each equation. We assume there are suitable exclusion restrictions on $\alpha \beta$ and $\chi$ to either exactly or over-identify the system. (This will be discussed further below.) The vector of exogenous variables is comprised of (1) bank-specific fundamentals, (2) macroeconomic fundamentals and (3) an index of political stability. As is clear from the above system, the initial model is fully simultaneous; each of the endogenous variables affects the other endogenous variables.

The bank-specific variables are constructed for each country based on data at the individual-bank level. In each case, individual country data are aggregated into a "country bank" and ratios calculated for this (fictitious) entity (see Appendix III for more details). ${ }^{7}$ They cover various aspects of bank performance. Profitability is measured as pre-tax operating income as a percentage of total assets. Asset quality is calculated as loan loss reserves as a percentage of impaired loans. The capital adequacy of the banks is equity as a percentage of total assets. Finally, the liquidity condition of the banks is captured by the interbank ratio, that is, funds lent in the interbank market to other

\footnotetext{
${ }^{7}$ This is not the same as simply averaging the banks indicators, to give an example, to construct the ratio of non-performing loans to total loans we would take the absolute value of NPLs for each bank, sum them up, sum total loans across the banks, and then calculate the ratio of the two sums. This automatically takes into account the relative size of the banks and effectively calculates the ratio for top banks in the banking system. (See also Appendix III.)
} 
banks divided by funds borrowed; if the ratio takes the value of 100 , then banks have a zero net interbank exposure - they lend as much as they borrow. A value higher than 100 implies that the bank is a net lender to the interbank market and, vice versa, for a value lower than 100 . For all four bank-specific variables, a rise in the ratio indicates a stronger financial situation; hence, we would anticipate that a rise in the ratio produces a rise in the bank equity indices.

We use the following variables to capture macroeconomic fundamentals. (1) Our fiscal variable is the general government consolidated gross debt-to-GDP ratio. Other things equal, the higher the debt-to-GDP ratio, the higher we would expect sovereign spreads to be and the lower a sovereign's rating (which, in our cardinal series, translates into a higher value). (2) Competitiveness is captured by including relative price levels (defined as each country's Harmonised Index of Consumer Prices -- HICP, all items index -- relative to that of Germany). A higher ratio of relative prices indicates a deterioration in competitiveness. (3) Growth is an important determinant of a country's ability to meet its obligations and hence we include the percentage change in real GDP as an explanatory variable.

As mentioned, we include an index of political stability; ${ }^{8}$ the IFO World Economic Survey index of political stability. A rise in the index indicates greater stability. Finally, in order to bring banks' ratings into our framework, we constructed a variable that measures banks' rating relative to sovereign rating for each country, and we include this variable in the bank equity index equation. (See Appendix III for details.)

It is important to consider the possibility that our 'exogenous' variables may not truly exogenous. In this paper, the general macroeconomic variables considered can be treated as exogenous. These variables move relatively slowly and smoothly over time, so that we would not expect, for example, any simultaneous feedback effects from spreads to GDP. A similar circumstance applies to some extent to the commercial-bank-specific variables. Nevertheless, some of these variables could react quickly enough to a bank's share price to raise possible doubts about exogeneity: the interbank ratio, for example,

\footnotetext{
${ }^{8}$ We follow Gibson, Hall, and Tavlas (2014), who found that an index of political stability helped explain sovereign spreads in Greece.
} 
might be affected by a bank's equity price. Political stability could also raise concerns about exogeneity as there are obviously close links between sovereign spreads and political uncertainty. We decided, however, not to expand the system further because there are clear costs of doing so. We did experiment with instrumenting the politicalstability variable within an unexpanded system, but this did not affect the final results in an important way.

Our data comprise an unbalanced panel covering, at its maximum, the period from October 1998 until July 2014, and the data are monthly; where they are quarterly or annual (bank-specific data), we interpolate them to a monthly frequency. As the raw data are available at different frequencies, we had to decide whether to aggregate the data up to the lowest frequency (annual in this case) or to interpolate the data to the highest frequency (monthly). Since the objective of this study is to explain commercial bank equity prices, which are available on a monthly frequency, aggregating these data would have led to a substantial loss of information. By contrast, most of the data which are available at low frequencies -- GDP, debt stocks, the fiscal deficit, etc. -- tend to move quite smoothly and so interpolating these data to a monthly series is relatively straightforward and should not distort the results.

The identification of the system is done, as usual, on the basis of theory. First, we assume that the bank-specific variables only affect the bank equity price, and not the sovereign rating or spread. As mentioned, however, the general simultaneous system provides a channel through which bank equity prices affect both sovereign ratings and sovereign spreads. We further assume that the macroeconomic variables do not directly enter the bank equity equation. Again, however, we allow for a possible effect of sovereign ratings and spreads on bank equity prices via the simultaneous system. The identification of the sovereign ratings and the spread equation is more problematic as one might expect the same variables to enter each equation. Here, we make the identifying assumptions that GDP growth affects the spread and that the debt-to-GDP ratio affects ratings. We also include lagged dependent variables in all three equations. Given the identifying restrictions, we estimate the model in its most general form and then employ a general-to-specific methodology to nest the model down to a 
parsimonious one based on successively excluding insignificant variables and/or variables with incorrect signs.

\section{Results}

The results, following the nesting down process, are displayed in Table $1^{9}$. The following findings merit comment.

First, focusing on the equation for the bank equity index, two of the four bankspecific balance-sheet variables are significant and correctly signed; (1) a rise in reserves held to meet potential defaults on non-performing loans ensures that banks are healthier -- a rise in the ratio reserves-to-non-performing loans is associated with a rise in the bank equity index; (2) higher profitability has a positive impact on the bank equity index.

Second, sovereign ratings play a substantial role in the determination of banks' equity, beyond the effects of the banking fundamentals. A deterioration in sovereign ratings (a rise in our ratings' index) causes the bank equity index to fall. This effect most likely reflects concerns about the ability of the country to meet the potential fiscal costs associated with its explicit or implicit banking system support (deposit guarantee schemes, possible capital injections, etc.). Indeed, it appears that changes in sovereign ratings have larger effects on bank's equity prices than changes in the bank-specific variables. Abstracting from dynamics, our findings indicate that a one-notch sovereign downgrade results in a fall in bank equity prices of 10 per cent. With the exception of Italy (which experienced a cumulative fall in sovereign ratings of only 4 notches), the other countries at the end of the period (mid-2014) were some 7-8 notches below their 2008 levels. Thus sovereign rating downgrades explain a large amount of the sharp falls in bank equity indices displayed in Figures 1-5, while bank-specific variables have much smaller effects. A 10 per cent fall in the loan-loss-reserves-to-nonperforming-loans ratio

\footnotetext{
${ }^{9}$ It can be noted that we use all available observations for each of the estimations in Tables 1 and 2. However, samples differ since the interbank ratio is available only from 2004 in 4 of the 5 countries. At the same time, the loan loss reserves to NPL ratio is only available in Greece from 2004. The system estimates, which do not contain the interbank ratio (since it was found to be insignificant), allow a larger sample to be used. It should also be noted that dropping the interbank ratio from Table 1 does not change qualitatively the results.
} 
causes a 3.6 per cent fall in equity prices; a 10 per cent fall in bank profitability causes equity prices to decline by almost 5 per cent.

Third, there are also significant spillover effects of sovereign ratings on banks' equity prices. Specifically, there are direct effects through the two variables measuring sovereign ratings and the difference between bank rating and sovereign rating. Sovereign ratings are also affected by the sovereign spread so that there is also an indirect effect of spreads on bank equity prices through sovereign ratings. However, it should be noted that in the case of Spain and Italy, bank ratings deteriorated at a slower rate than the ratings of the sovereign. This behaviour implies that the differential between bank and sovereign rating had a positive effect on bank equity prices in these countries.

Fourth, if banks are downgraded at the same pace as the sovereign -- that is, there is no change in the variable representing the difference between bank ratings and sovereign ratings -- there is no effect on the bank equity prices apart from the effect of downgrades of the sovereign, which has a negative effect (with a coefficient of -0.13 ). However, if banks are downgraded at a faster pace than the sovereign -- indicating more of a banking crisis rather than a sovereign crisis -- the total effect of the two downgrades on bank equity prices is about three times larger than if sovereign downgrades occur at the same pace as bank downgrades; that is, the combined effect is -0.35 instead of -0.13 .

Fifth, our results point to the importance of using levels of equity prices -- rather than rates of return -- in measuring banks' performance. The use of levels allows us to derive the determinants of long-run equity prices. Moreover, our focus on levels indicates that if sovereign ratings deteriorate, bank equity prices go down -- and remain down -- until sovereign ratings improve.

Sixth, sovereign spreads are determined mainly by economic fundamentals, as reflected in real growth and relative prices, and sovereign ratings, while sovereign ratings are determined primarily by the sovereign's debt ratio, political uncertainty, and the simultaneous effect of sovereign spreads. There are also strong dynamic effects at work in the equations for sovereign spreads and sovereign ratings. 
We also investigated the possibility of non-linear effects of ratings on spreads by including a term in the squared value of ratings. The inclusion of this variable allows major downgrades to have a much larger effect on spreads than more minor ones. This effect did not prove to be significant (t-statistic of 0.7 ).

To summarize, our findings indicate that a long-run recursive relationship between sovereigns and banks operated during the euro-area crisis. Specifically, for the five crisis countries considered shocks to sovereign spreads fed-through to sovereign ratings, which affected the equity performance of commercial banks. Indeed, our results suggest that during the euro-area crisis, a predominant part of the decline in banks' share prices reflected direct and indirect impacts from the sovereign sector. The combined effect of the average change in sovereign ratings across countries, along with the average change in the differential between bank and sovereign ratings, explains somewhat more than half of the actual fall in bank equity prices. In three of the programme countries (Greece, Ireland and Portugal), this combined effect explains over 90 per cent of the fall in bank equity prices. The cases of Spain and Italy, where bank ratings deteriorated by less than those of the sovereign between 2008 and 2014, highlight the need of further work examining the impact of banks on sovereigns, and not just the impact of sovereigns on bank equity prices as done in this study.

\section{Conclusions}

During the course of 2014, several important actions were taken toward the creation of a banking union in the euro area. ${ }^{10}$ These actions will go a long way in reducing the strength of the linkages between sovereigns and banks, linkages that played out during the recent crisis, deepening on the intensity of the crisis. Our results, however, suggest that a banking union may be a necessary, but not a sufficient, condition for financial stability. As long as domestic euro-area banks hold relatively-large shares of debt issued by their respective national sovereigns in their portfolios -- and in the absence of a mechanism that ensures some form of debt mutualization -- the

\footnotetext{
10 These include the establishment of a Single Supervisory Mechanism in November 2014. A Single Resolution Mechanism will be fully operational on January 1, 2016.
} 
potential will exist for a re-emergence of the interactions between sovereign spreads and sovereign ratings, on the one hand, and banks' performance, on the other.

Why might a debt-mutualization mechanism contribute to financial stability? After all, our empirical results indicate that rises in our measures of sovereign risk -sovereign ratings and sovereign spreads -- lead to declines (both directly and indirectly) in banks' equity prices. Consequently, these results could be interpreted as the correct market reaction so that debt mutualization might not be necessary. The following points, however, need to be considered. First, the negative relationship we obtained between measures of sovereign risk and banks' equity prices was obtained inclusive of the period after the outbreak of the 2007-08 global financial crisis. Yet, as indicated in Figures 1 through 5, during the period from the early 2000s until 2007 and 2008, bank equity prices rose for the five countries considered in this paper, while the two measures of sovereign risk were essentially unchanged. It was only after the crisis erupted that a significant negative relationship between banks' equity prices and sovereign risk emerged. In other words, market discipline occurred late in the day -- this discipline was too late to prevent the outbreak of the crisis. Second, a debtmutualization mechanism would undoubtedly involve features such as increased surveillance and stricter fiscal rules on members of the mechanism, enhancing discipline. For these reasons, we believe that debt mutualization would represent a significant step forward in crisis prevention. 


\section{References}

Aizenman, A, Hutchison, $M$ and Jinjarak, $Y$ (2013) 'What is the risk of European sovereign debt defaults? Fiscal space, CDS spreads and market pricing of risk' Journal of International Money and Finance, 34, 37-59.

Aizenman, A, Hutchison, M and Lothian, J (2013) 'The European sovereign debt crisis: background and perspectives' Journal of International Money and Finance, 34, 1-5.

Ammer, J, and Cai, F (2007) 'Sovereign CDS and bond pricing dynamics in emerging markets: does the cheapest-to-deliver option matter?' International Finance Discussion Papers 912, Board of Governors of the Federal Reserve System (U.S.).

Beirne, J and Fratzscher, M (2013) 'The pricing of sovereign risk and contagion during the European sovereign debt crisis', Journal of International Money and Finance, 34, 60-82.

BIS (2011) 'The impact of sovereign credit risk on bank funding conditions', Committee on the Global Financial System, CGFS Papers, no. 43.

Castrén, O, Fitzpatrick, T and Sydow, M (2006) 'What drives EU banks' stock returns? Bank level evidence using the dynamic dividend-discount model', ECB Working Paper, no. 677.

Chan-Lau, J A, Liu, E X and Schmittmann, J M (2014) 'Equity returns in the banking sector in the wake of the Great Recession and the European sovereign debt crisis', Journal of Financial Stability, forthcoming.

De Grauwe, P and Ji, Y (2013) 'Self-fulfilling crises in the euro zone: an empirical test', Journal of International Money and Finance, 34, 15-36.

Demirgüç-Kunt, A, Detragiache, E and Merrouche O(2013) 'Bank capital: lessons from the financial crisis', Journal of Money, Credit and Banking, 45, 1147-64.

Dötz, N and Fischer, C (2010) 'What can EMU countries' sovereign bond spreads tell us about market perceptions of default probabilities during the recent financial crisis?' Deutsche Bundesbank, Discussion Papers, Series 1: Economic Studies, no. 11.

Fontana, A and Scheicher, M (2010) 'An analysis of euro area sovereign CDS and their relation with government bonds', ECB Working Paper, no. 1271.

Gerlach, S, Schulz, A and Wolff, G B (2010) 'Banking and sovereign risk in the euro area', CEPR Discussion Paper, no. 7833.

Gibson, H D, Hall, S G and Tavlas, G S (2012) 'The Greek financial crisis: growing imbalances and sovereign spreads', Journal of International Money and Finance, 31, 498-516.

Gibson, H D, Hall, S G and Tavlas, G S (2014) 'Fundamentally wrong? Market pricing of sovereigns and the Greek financial crisis', Journal of Macroeconomics, 39b, 405-419.

O' Rourke, K, and Taylor, A, (2013) 'Cross of Euros' Journal of Economic Perspectives 27 (3), 167 192.

Pisani-Ferry, J (2014) 'The Euro Crisis and its Aftermath', Oxford University Press, Oxford, U.K. Shambaugh, (2012) 'The euro's three crises', Brookings Pap. Econ. Act. 44 (1), 157-231.

Yang, J and Tsasaronis, K (2012) 'Bank stock returns, leverage and the business cycle', BIS Quarterly Review, March, 45-59. 
Table 1: Final Results of System Estimation after Nesting Down

\begin{tabular}{|c|c|c|c|c|c|}
\hline & & Coefficient & Std. Error & t-Statistic & Prob. \\
\hline Spain - constant & & -0.02 & 0.05 & -0.4 & 0.66 \\
\hline Greece - constant & & -0.14 & 0.1 & -1.4 & 0.16 \\
\hline Ireland - constant & & 0.05 & 0.03 & 1.5 & 0.14 \\
\hline Italy - constant & & -0.11 & 0.08 & -1.4 & 0.15 \\
\hline Portugal - constant & spread & -0.09 & 0.08 & -1.1 & 0.26 \\
\hline $\begin{array}{c}\text { Current account to } \\
\text { GDP }\end{array}$ & equation & -0.32 & 0.46 & -0.7 & 0.48 \\
\hline Relative prices & & 1.01 & 0.46 & 2.2 & 0.02 \\
\hline Growth & & -7.57 & 3.34 & -2.3 & 0.02 \\
\hline Sovereign rating & & 0.03 & 0.02 & 1.8 & 0.08 \\
\hline Lagged spread & & 0.97 & 0.03 & 37.8 & 0.00 \\
\hline Spain - constant & & -0.28 & 0.05 & -5.1 & 0.00 \\
\hline Greece - constant & & -0.40 & 0.08 & -5.0 & 0.00 \\
\hline Ireland-constant & & -0.22 & 0.05 & -4.9 & 0.00 \\
\hline Italy - constant & Sovereign & -0.61 & 0.10 & -5.8 & 0.00 \\
\hline Portugal - constant & ratings & -0.21 & 0.05 & -4.1 & 0.00 \\
\hline Relative prices & equation & 0.64 & 0.30 & 2.1 & 0.04 \\
\hline Debt-to-GDP & & 0.009 & 0.001 & 6.1 & 0.00 \\
\hline Spread & & 0.04 & 0.01 & 5.0 & 0.00 \\
\hline Lagged ratings & & 0.90 & 0.01 & 49.7 & 0.00 \\
\hline Spain - constant & & 5.14 & 0.20 & 21.2 & 0.00 \\
\hline Greece - constant & & 6.31 & 0.30 & 21.2 & 0.00 \\
\hline Ireland - constant & & 6.61 & 0.21 & 31.7 & 0.00 \\
\hline Italy - constant & & 4.88 & 0.17 & 28.2 & 0.00 \\
\hline Portugal - constant & Banks & 4.50 & 0.24 & 118.3 & 0.00 \\
\hline LLR/NPLs & index & 0.004 & 0.0009 & 4.0 & 0.00 \\
\hline Profits/TA & & 0.87 & 0.08 & 10.5 & 0.00 \\
\hline $\begin{array}{l}\text { Bank rating - } \\
\text { sovereign rating }\end{array}$ & & -0.21 & 0.04 & -4.7 & 0.00 \\
\hline Sovereign rating & & -0.10 & 0.02 & -4.3 & 0.00 \\
\hline $\begin{array}{l}\text { Determinant residual cc } \\
\text { J-statistic }\end{array}$ & covariance & $\begin{array}{l}0.017 \\
0.043\end{array}$ & & & \\
\hline
\end{tabular}

Overall sample October 1998 to July 2014

Total number of observations of $\mathbf{2 4 5 5}$ 


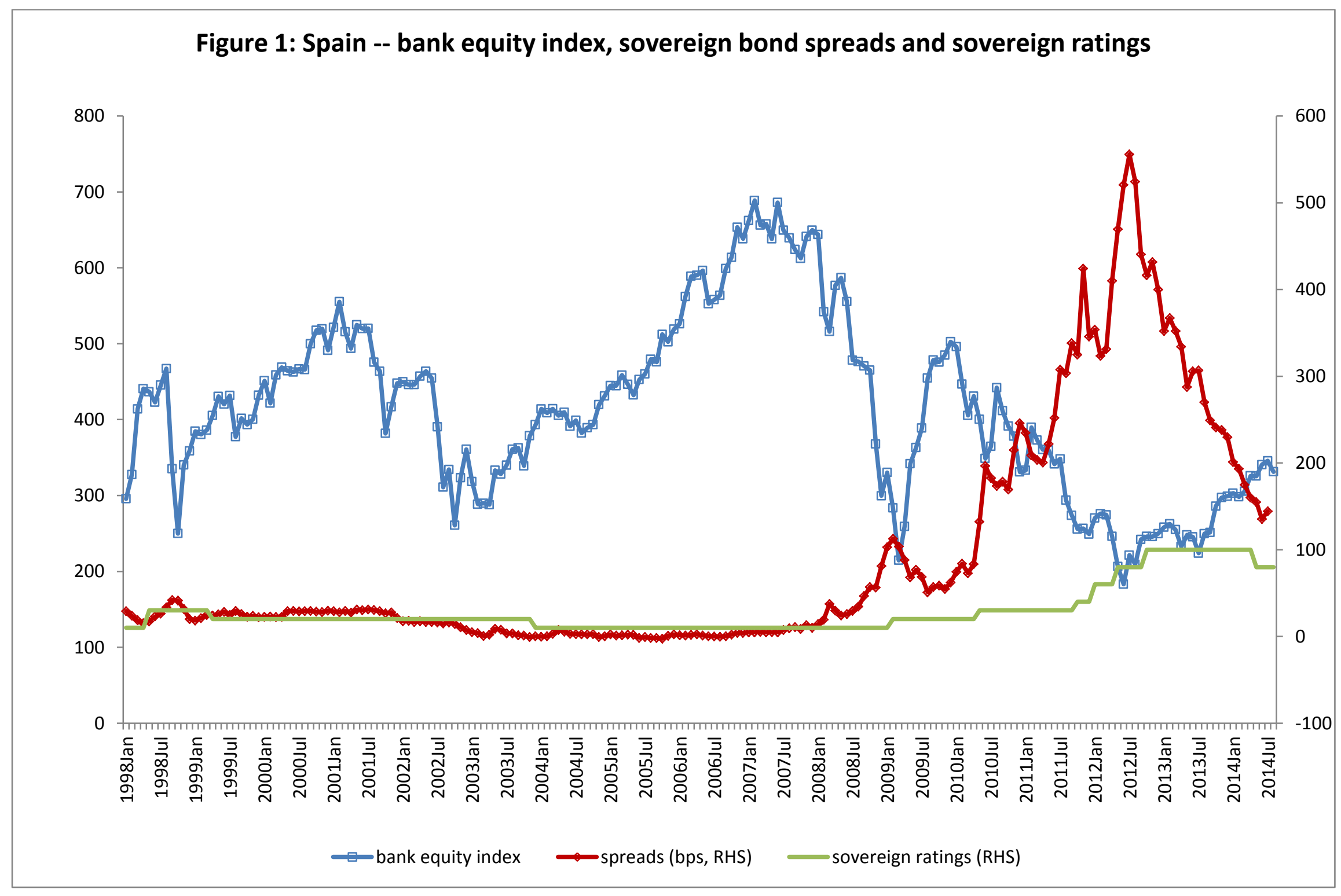




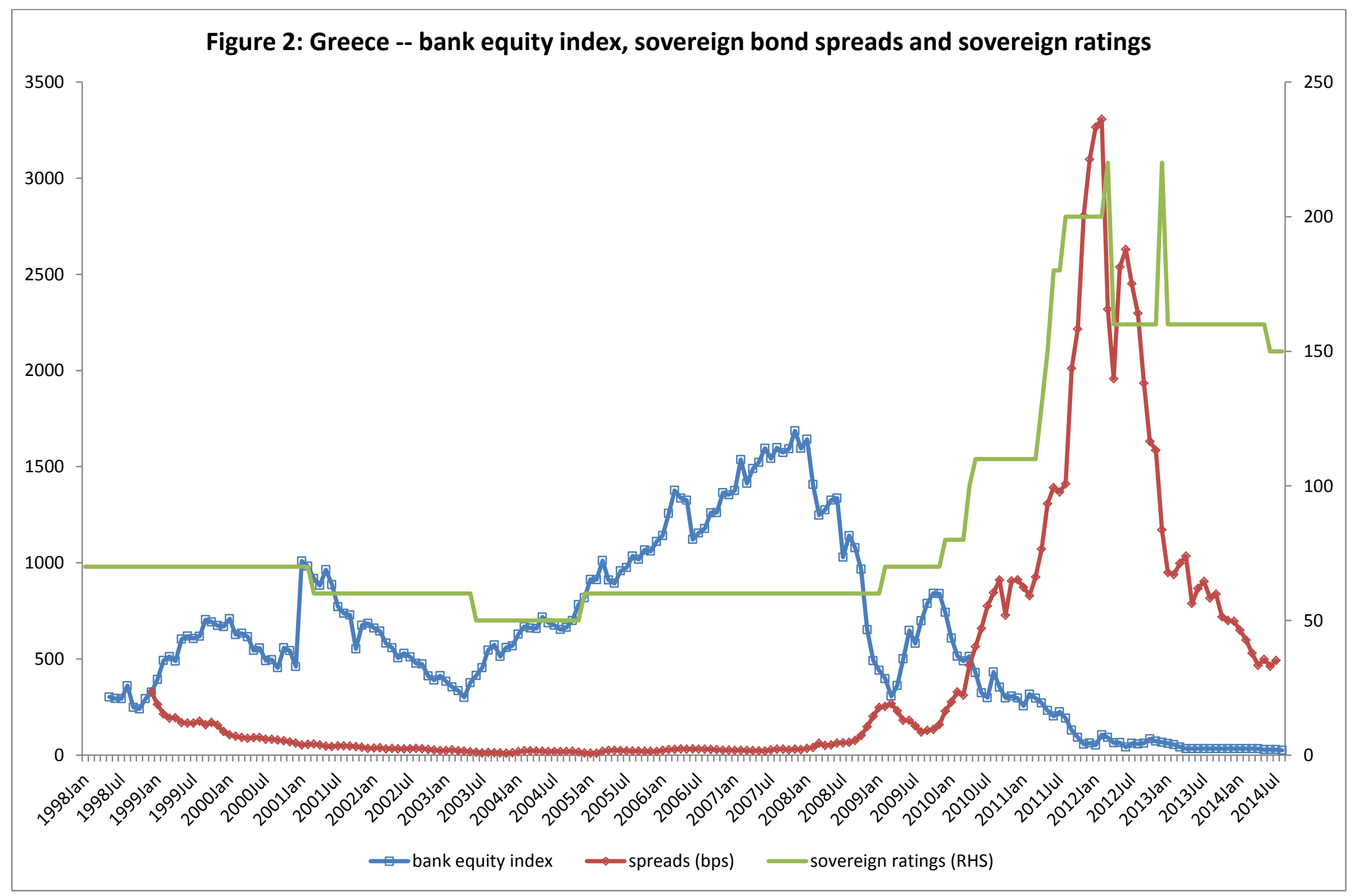




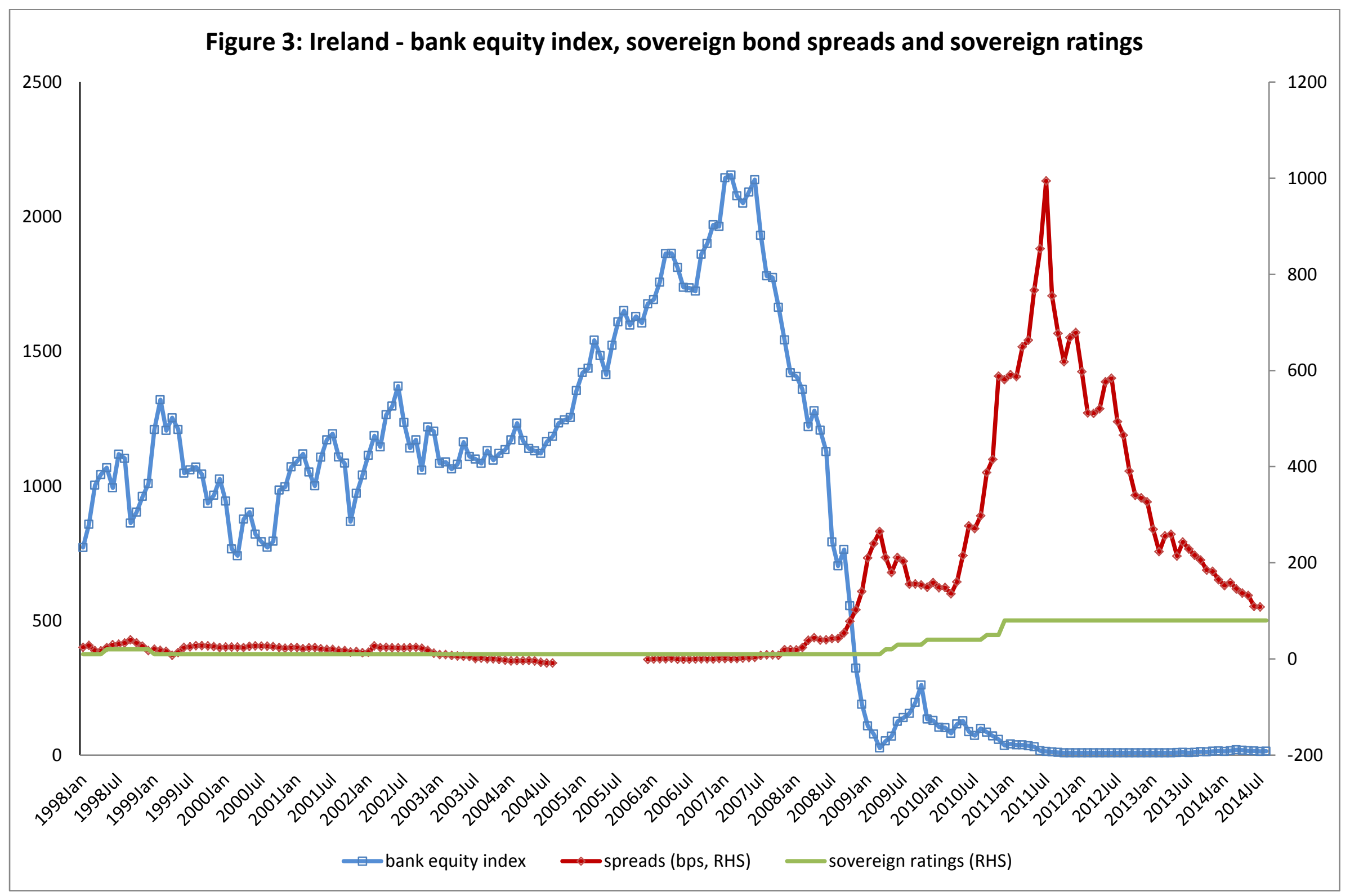




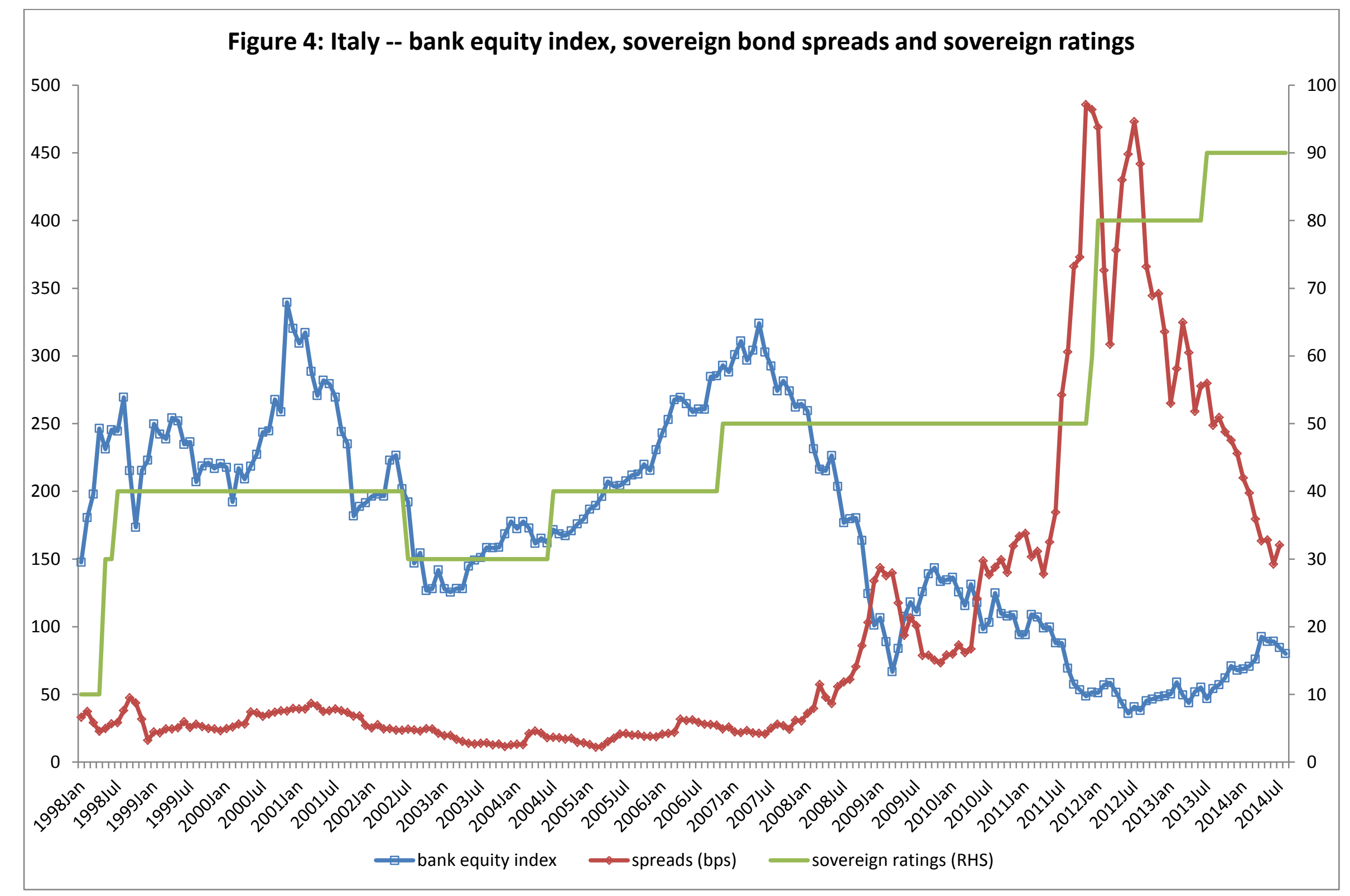




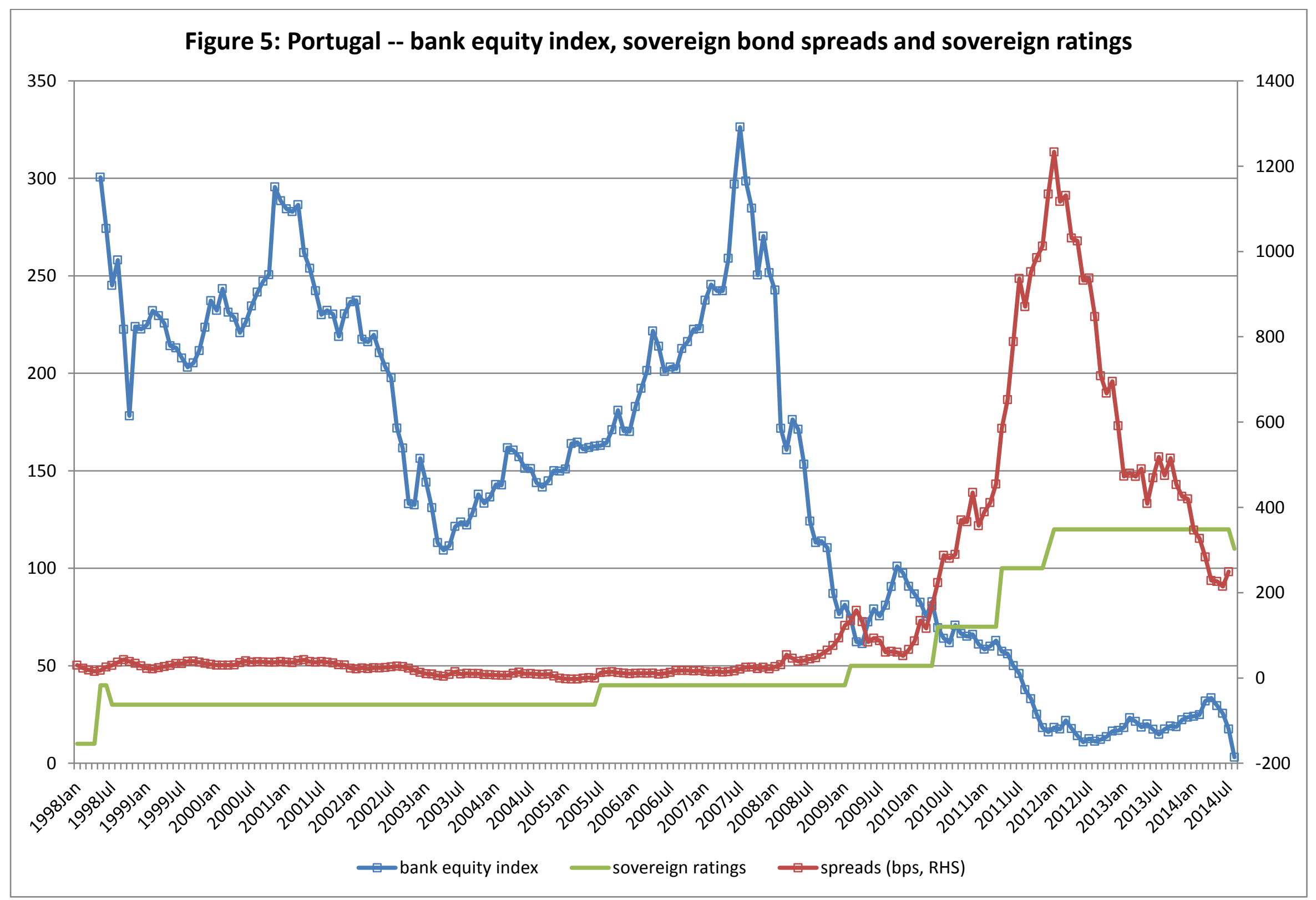



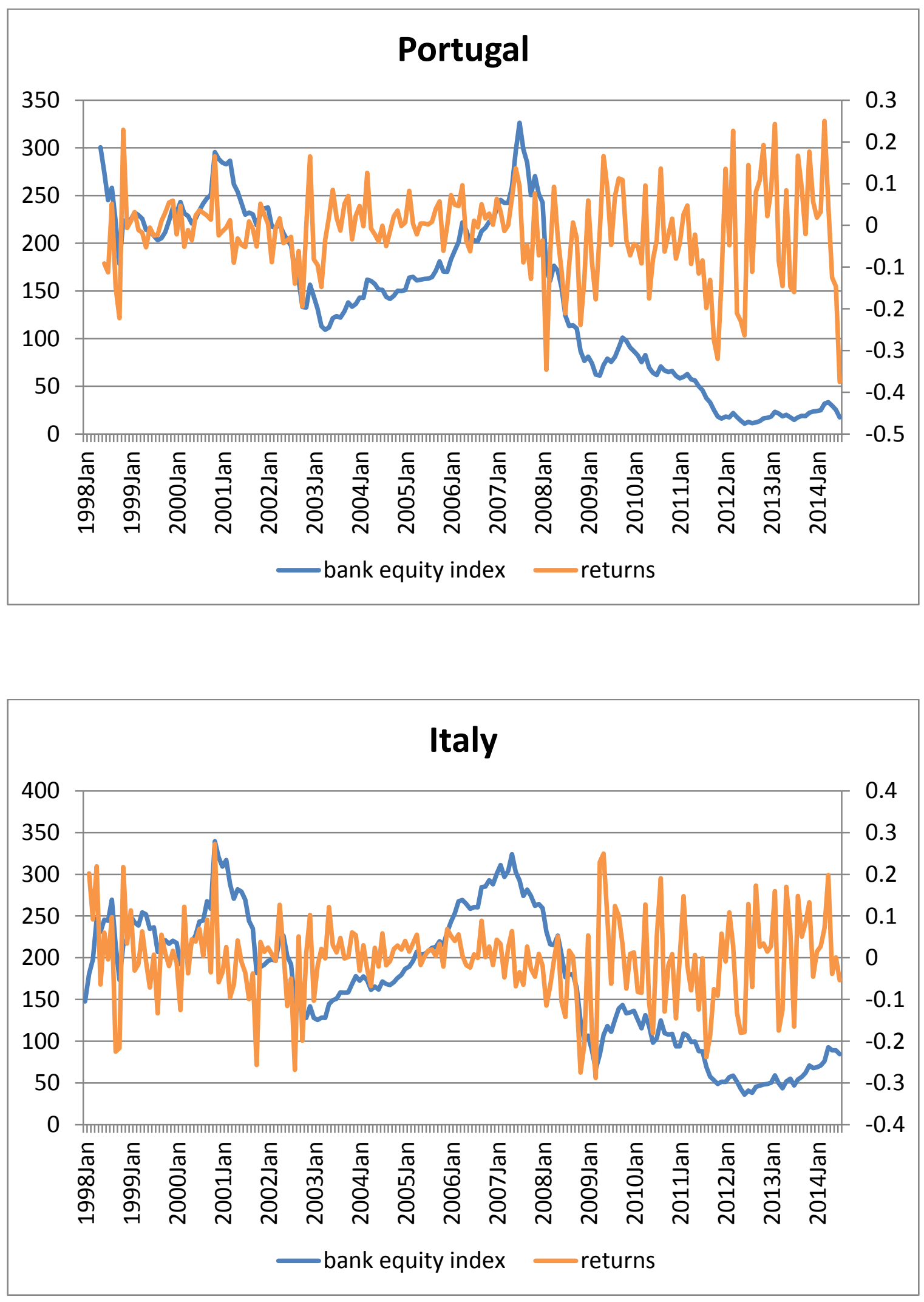

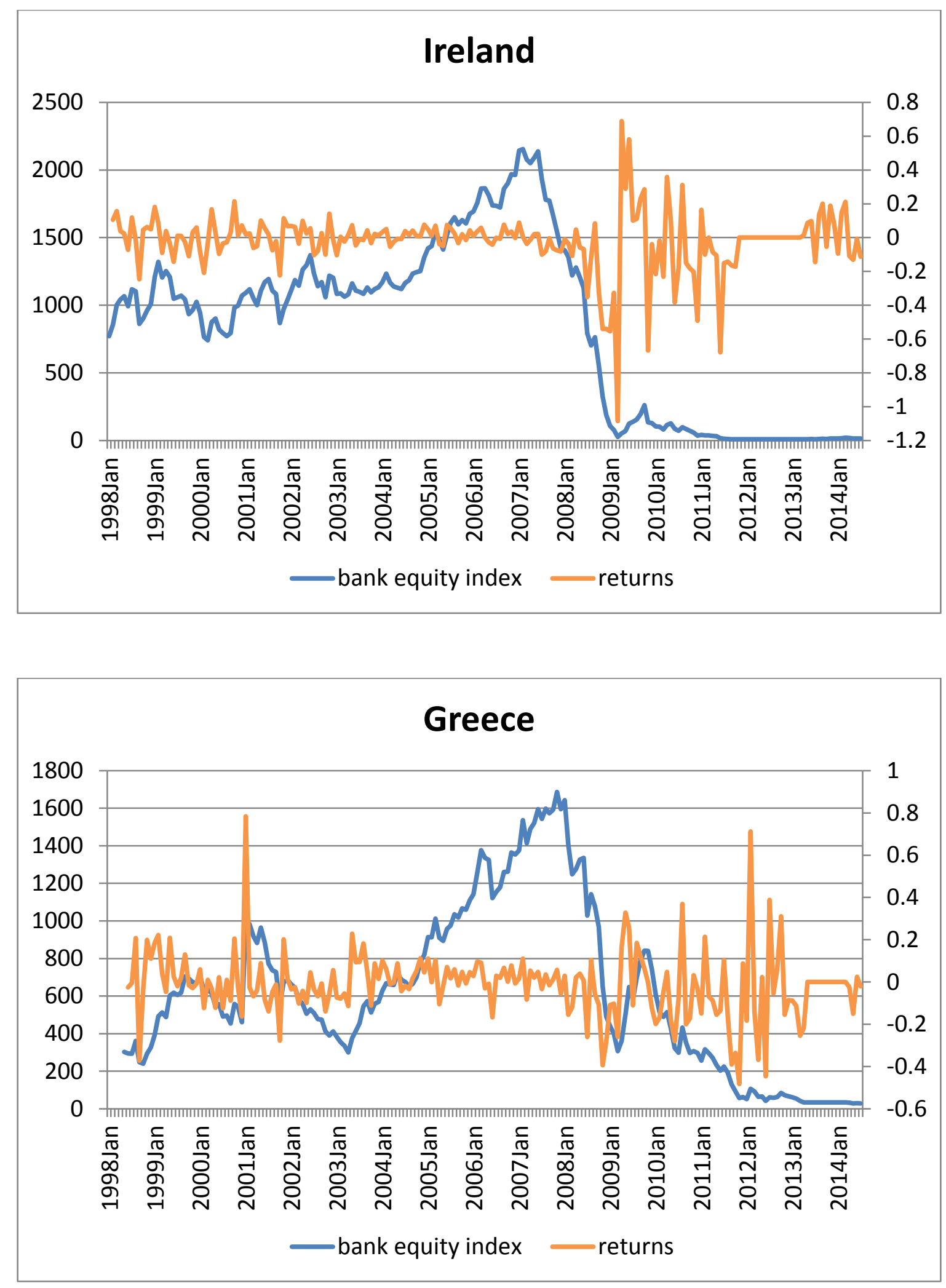


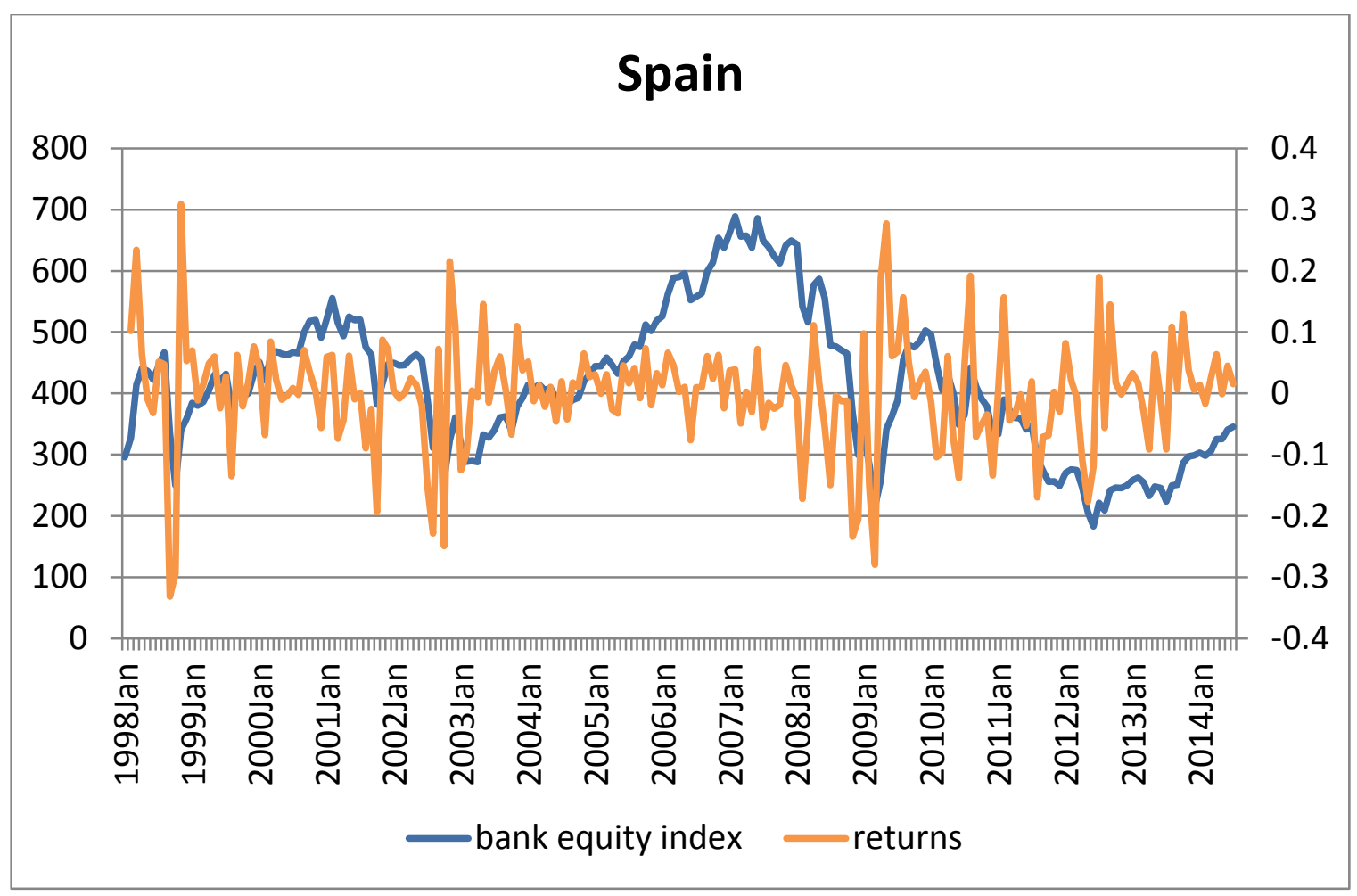


Appendix II: data sources

FTSE banking sector index 10-year government bond yields

Datastream-Reuters

Sovereign ratings

ECB Statistical Data Warehouse

Internet sites of rating agencies

Bank ratings

Bloomberg

Macroeconomic data

Datastream-Reuters

Fiscal news

Spring, Autumn Forecasts, European

Commission

Political Stability

IFO World Economic Survey

index of political stability

Datastream-Reuters

Bank specific data

Bankscope 


\section{Appendix III: Banks included in sample}

In order to construct the bank-specific variables we use the banks below. The choice was made on the basis of (i) size of the bank; (ii) availability of data for the years 2000-2014. Data for 2000-2013 is taken from Bankscope. Data for 2014 is taken directly from banks' half-year results. As noted in the main text, the bank-specific indicators are calculated for each country by aggregating data from the individual banks and then calculating the ratios.

Spain: Banco Sandander, Banco Bilbao Vizcaya Argentaria, Caja de Ahorros y Pernsiones de Balcelona

Greece: National Bank of Greece, Piraeus Bank, Eurobank Ergasias, Alpha Bank Ireland: Bank of Ireland, Allied Irish Banks

Italy: UniCredit, Intesa Sanpaolo, Banca Monte dei Paschi di Siena

Portugal: Caixa Geral de Depositos, Banco Comercial Portugues, Banco Espirito Santo

For bank ratings, we convert the ordinal ratings to cardinal ones (in the same manner as for sovereign ratings) for the top 2 banks in each country (top 4 in Greece) and then take the arithmetic average, thus generating the variable "bank rating" for each country over time. 